\title{
Radiocarbon
}

1971

\section{BIRMINGHAM UNIVERSITY RADIOCARBON DATES V}

\author{
F. W. SHOTTON and R. E. G. WILLIAMS
}

The University of Birmingham, Birmingham, England

The following list comprises results obtained during 1970 from both the $1 \mathrm{~L}$ and $6 \mathrm{~L}$ counters. Results are not corrected for $\mathrm{C}^{13}$ fractionation. Errors quoted refer only to the standard deviation calculated from a statistical analysis of sample and background count rates and the Libby half-life of $5570 \pm 30 \mathrm{yr}$. Pretreatment has been continued as described previously (R., 1969, v. 11, p. 263). In cases where sample size was insufficient for full pretreatment, details of the necessary deviations accompany the result.

\section{ACKNOWLEDGMENTS}

We acknowledge with pleasure the advice of D. J. Blundell, who has been closely associated with the laboratory since its inception. We thank Mrs. L. Salvini for routine sample preparation and Mrs. J. Clarke for assistance with the counting.

\section{SAMPLE DESCRIPTIONS}

I. GEOLOGIC SAMPLES

\section{A. British Isles}

\section{Birm-146. Cae Gwyn Caves, Tremerchion,} N Wales

$$
\begin{gathered}
18,000+1400 \\
16,050 \text { в.C. }
\end{gathered}
$$

Collagen from carpal bone of mammoth underlying Upper Boulder Clay ca. $200 \mathrm{~m}$ ENE of Ffynnon Beuno Farm at entrance to Cae Gwyn cave, Tremerchion, N Wales (53 $14^{\prime} \mathrm{N}$ Lat, $3^{\circ} 22^{\prime} \mathrm{W}$ Long, Grid Ref. SJ086724). Coll. I893-6 by H Hicks; subm. by B. M. Rowlands, Dept. of Geog., Univ. of Liverpool. Comment: provides limit to Irish Sea Glaciation which deposited Upper Boulder Clay (Penny, 1964).

\section{Ipsley series, Worcestershire}

Samples from alluvium $2.85 \mathrm{~m}$ thick which contained an alleged monoxylous boat at Ipsley, Worcestershire $\left(52^{\circ} 17^{\prime} \mathrm{N}\right.$ Lat, $1^{\circ} 54^{\prime} \mathrm{W}$ Long, Grid Ref. SP067652). Birm-160 coll. and subm. by D. J. Tomalin; Birm-163 and Birm-164 coll. by R. E. G. Williams and subm. by F. W. Shotton.

Birm-160.

Outermost wood from solid boat or drifted trunk of Quercus, lying between 1.5 and $1.8 \mathrm{~m}$ depth. 
Birm-164.

$3425 \pm 125$

Wood fragments in organic silt between 1.75 and $1.93 \mathrm{~m}$ depth.

$5075 \pm 110$

Birm-163.

3125 B.C.

Wood fragments in dark clay between 2.69 and $2.82 \mathrm{~m}$ depth. General Comment: date for alleged solid boat is included with the 2 alluvium samples, as it could be interpreted as a naturally split and eroded trunk of Quercus. As a series, the figures are consistent and date the near commencement and progress of alluviation in a tributary of the Warwickshire Avon.

\section{Birm-162. Seisdon, Staffordshire}

Plant washed from gray silt at $4.6 \mathrm{~m}$ depth at Lowes Pit, Seisdon, Staffordshire $\left(52^{\circ} 33^{\prime} 05^{\prime \prime}\right.$ N Lat, $2^{\circ} 13^{\prime} 34^{\prime \prime}$ W Long, Grid Ref. SO 846949). Coll. 1969 and subm. by A. V. Morgan, Dept. of Geol., Univ. of Birmingham. Comment: cf. Birm-114, (R., 1970, v. 12, p. 385) for inner fraction of opercula shells from site ca. $200 \mathrm{~m} \mathrm{ESE} / \mathrm{E}$ and from higher horizon (Morgan, A. V., 1970). Date agrees with evidence of fauna and flora that deposit is interglacial.

\section{Four Ashes series, Staffordshire}

Samples from small separated lenses of peat or organic silt in Four Ashes Gravel, Staffordshire (52 $42^{\prime} 13^{\prime \prime} \mathrm{N}$ Lat, $2^{\circ} 07^{\prime} 24^{\prime \prime}$ W Long, Grid Ref. SJ916082). Coll. 1969 and subm. by A. V. Morgan. The gravel underlies "Irish Sea" till.

General Comment: gravel covers 1 st $2 / 3$ of the Devensian (Weichselian) from undatable Ipswichian to 30,000 B.P. at earliest. Other dates from this site: Birm-24, 36,340 ${ }_{-700}^{+770}$; Birm-25, 30,655 ${ }_{-700}^{+765}$; Birm-56, 42,530 +1345
-1115 (R., 1968, v. 10, p. 200-201) Birm-74, >43,500 (R., 1970, v. 12, p. 385; Shotton, 1967).

Birm-170.

Peat from lens at ca. $4.6 \mathrm{~m}$ depth (Site 12). Comment: insect fauna includes a few thermophilous species and indicates warmer phase of interstadial.

Birm-171.

Wood from organic silt ca. $25 \mathrm{~cm}$ thick at base of Four Ashes Gravel (Site 44). Comment: wood, macroflora, and pollen indicate an interglacial, hence Ipswichian.

Birm-195.

$30,500 \pm 440$

28,550 в.c.

Twigs and plant material washed from gray silt 2.1 to $2.3 \mathrm{~m}$ below 
surface in Four Ashes Gravel (Site 45) laterally close to Birm-171 but $1 \mathrm{~m}$ higher. Comment: assoc. insect fauna has many arctic stenotherms but lacks typical S species of Upton Warren type. Sample from Site 2 (Birm-25) has similar fauna.

Birm-196.

$$
40,000+1400
$$

Peat from ca. $2.1 \mathrm{~m}$ below surface in Four Ashes Gravel (Site 34). Comment: sample lacks arctic stenotherms and reaffirms apparent amelioration ca. 38,000 to 42,000 B.P. (A. Morgan, 1970).

\section{Birm-179. Gills Bay, Caithness, Scotland \\ (a) $>40,800$}

Inner (a) and outer (b) fraction of shells (Turritella) (b) $>\mathbf{3 4 , 7 0 0}$ $1 \mathrm{~m}$ wide at depth 2.5 to $3.5 \mathrm{~m}$ in exposed till section ca. $6 \mathrm{~m}$ thick at Gills Bay, Caithness, Scotland (58 $38^{\prime} 44^{\prime \prime}$ N Lat, $3^{\circ} 09^{\prime} 52^{\prime \prime} \mathrm{W}$ Long, Grid Ref. ND322733). Coll. 1969 and subm. by D. Omand, Dept. of Geog., Univ. of Strathclyde, Glasgow. Comment: confirms date on similar shelly till at Berwick (Sissons, 1967) and compares with Birm-191 below.

\section{Birm-191. Gardenstown, Banf hire, Scotland}

below surtact fo $+53 \mathrm{~m}$ alt) in boulder clay $700 \mathrm{~m}$ approx. NNW of Findon at Castle Hill, Gardenstown, Banffshire, Scotland $\left(57^{\circ} 40^{\prime}\right.$ 06" N Lat, 2 ${ }^{\circ} 20^{\prime}$ 42" W Long, Grid Ref. NJ942439). Coll. 1966 and subm. by J. D. Peacock, Inst. of Geol. Sci., Edinburgh. Comment (J.D.P.): sample obtained from beds formerly equated with Coastal Deposits of Banffshire (Jamieson, 1906; Read, 1923) but now referred to Shelly Boulder Clay. Date excludes Late Glacial age as expected, but unfortunately is infinite. Cf. Birm-179 above $(>40,800)$ obtained from Shelly Boulder Clay of Caithness.

\section{Birm-184. Marlow, Buckinghamshire}

Plant detritus washed from organic silt in gravel of $3 \mathrm{~m}$ terrace of $\mathrm{R}$. Thames at Little Marlow Village, Buckinghamshire $\left(51^{\circ} 30^{\prime} \mathrm{N}\right.$ Lat, $0^{\circ} 45^{\prime}$ W Long, Grid Ref. SO865874). Coll. 1966 by C. Ranson; subm. by F. G. Bell, Dept. of Geol., Univ. of Birmingham. Comment: although infinite, determination agrees with Upton Warren Interstadial age suggested by thermophilous insect assemblage, which contains several species unique to these 2 sites. Pollen diagram indicates treeless conditions (Bell, 1968; 1969).

\section{South West Scotland Coastal series}

Samples from organic beds underlying, overlying, or within marine deposits of Flandrian transgression. Coll. and subm. by W. G. Jardine, Dept. of Geol., Univ. of Glasgow. Comments also by W.G.J. 


\section{Birm-187.}

Wood, $7.5 \mathrm{~cm}$ deep $(+1.8 \mathrm{~m}$ alt $)$ in gray organic silt ca. $33 \mathrm{~cm}$ thick above gray gravel at Girvan Railway Bridge, Ayrshire $\left(\begin{array}{ll}55^{\circ} & 15^{\prime}\end{array}\right.$ $\mathrm{N}$ Lat, $4^{\circ} 51^{\prime} \mathrm{W}$ Long, Grid Ref. NX190985). Coll. 1969. Comment: sample from base of same gray organic silt dated at $9020 \pm 120$; (Q-640, R., 1962, v. 4, p. 60).

\section{Birm-190.}

$8420 \pm 150$

Wood washed from top $5 \mathrm{~cm}$ (ca. $+6.8 \mathrm{~m}$ alt) of peat immediately underlying beach sand of Flandrian transgression at Turnberry Bridge, Ayrshire (55 $18^{\prime} \mathrm{N}$ Lat, $4^{\circ} 50^{\prime} \mathrm{W}$ Long, Grid Ref. NS202063). Coll. 1966. Comment: dates maximum age at start of Flandrian transgression in Ayrshire (Jardine, 1967).

\section{Birm-188.}

$7960 \pm 350$

Wood at $+6.3 \mathrm{~m}$ alt at junction of Flandrian marine/estuarine sediments and underlying fluvioglacial gravel from Bargaly borehole in valley of Palnure Burn S of Newton Stewart $\left(54^{\circ} 58^{\prime} \mathrm{N}\right.$ Lat, $4^{\circ} 24^{\prime}$ W Long, Grid Ref. NX596589). Coll. 1969. Comment: sample obtained by percussive drilling and assoc. with fluvioglacial gravel rather than with marine/estuarine clay above. Date therefore is pre-Flandrian transgression but not necessarily immediately so.

\section{Birm-189.}

$6240 \pm 240$

Wood at $+4.25 \mathrm{~m}$ alt at base of thick (ca. $4.73 \mathrm{~m}$ ) peat overlying estuarine clays in Palnure borehole, Newton Stewart, Kirkcudbrightshire (54 $56^{\circ} \mathrm{N}$ Lat, 4 25' W Long, Grid Ref. NX45006367). Coll. 1969. Comment: dates erosion and terrace deposition in Wigtown Bay area.

\section{Birm-219.}

$$
\mathbf{7 4 5 0} \pm \mathbf{2 0 0}
$$

Wood from thin layer of organic silt at $+6.34 \mathrm{~m}$ alt within Flandrian estuarine/marine deposits in bank of Palnure Burn, opp. Little Park Farm, Kirkcudbrightshire $\left(54^{\circ} 57^{\prime} \mathrm{N}\right.$ Lat, $4^{\circ} 24^{\prime} \mathrm{W}$ Long, Grid Ref. NX45006576). Coll. 1969. Comment: dates early marine deposition (cf. Birm-188 above).

\section{Birm-221.}

$3944 \pm 190$

Wood from base of thin peat bed at $+10.4 \mathrm{~m}$ alt overlain by blown sand and underlain by marine sand of Flandrian transgression in excavation at Woodside sandpit, Irvine, Ayrshire $\left(55^{\circ} 35^{\prime} \mathrm{N}\right.$ Lat, $4^{\circ} 39^{\prime}$ W Long, Grid Ref. NS330367). Coll. 1970. Comment: postdates regression of Flandrian sea from its maximum in Irvine area. 


\section{Newbie Cottage series, Solway Firth shore, Dumfriesshire}

Samples from succession of Flandrian marine deposits overlain by blown sand and underlain by peaty silt.

\section{Birm-218. $140 \mathrm{~m}$ SE of Newbie Cottages}

car Colway Firth, from thin carbonaceous layer at $+9.53 \mathrm{~m}$ alt within blown sand overlying Flandrian sediments at $+7.75 \mathrm{~m}$ alt $\left(54^{\circ} 58^{\prime} \mathrm{N}\right.$ Lat, $3^{\circ} 17^{\prime} \mathrm{W}$ Long, Grid Ref. NY168648). Coll. 1970. Comment: date is within period of local accumulation of blown sand; cf. Birm-220 below and I-5070 (in press), which antedate accumulation of sand.

\section{Birm-220. $66 \mathrm{~m} \mathrm{~W}$ of Newbie Co $5630 \pm 116$}

Wood from lower part of thin peat bed at junction of blown sand above and Flandrian sediments below $(+7.78 \mathrm{~m}$ alt $)$ at top of low cliff on $\mathrm{N}$ shore of Solway Firth (54 $58^{\prime} \mathrm{N}$ Lat, 3० $18^{\prime} \mathrm{W}$ Long, Grid Ref. NY167649). Coll. 1970. Comment: dates approx. beginning of local peat growth, maximum for beginning of accumulation of blown sand, and approx. end of Flandrian marine transgression. At other sites on $\mathrm{N}$ shore of Solway Firth, peat growth began before end of marine transgression because of local abnormal conditions (Q-638, 6645 \pm 120 ; R., 1962 , v. 4, p. 59 , Q-818, $6244 \pm 140$; R., 1965, v. 7, p. 211; Birm-189 above, $6240 \pm 246$ ).

\section{Birm-222. $169 \mathrm{~m}$ W of Newbie Coutages \\ Peaty silt at +2.95 5590 B.C.}

lying Flandrian $+2.95 \mathrm{~m}$ alt taken by auger from top of bed underRef NYandrian marine deposits $\left(54^{\circ} 58^{\prime} \mathrm{N}\right.$ Lat, $3^{\circ} 18^{\prime} \mathrm{W}$ Long, Grid Ref. NY166650). Coll. 1970. Comment: dates approx. beginning of Flandrian transgression along Dumfriesshire shore of Solway Firth. Agrees broadly with GU-64, $7254 \pm 101$ and GU-65, $7426 \pm 136$ from nearby sites (R., 1969, v. 11, p. 50-51).

\section{Birm-197. Porth Mear Cove, Cormwall}

Plant washed from organic clay, lower of 2 clay beds in Younger Head at Porth Mear Cove, Cornwall $\left(50^{\circ} 30^{\prime} 15^{\prime \prime} \mathrm{N}\right.$ Lat, $5^{\circ} 02^{\prime} 00^{\prime \prime}$ W Long, Grid Ref. SW849715). Coll. 1969 and subm. by Rev. B. B. Clarke. Comment: sample from ca. $.91 \mathrm{~m}$ into cliff face as material at $50 \mathrm{~cm}$ in was contaminated with Cafius. Date indicates material is alluvial, derived from older head deposits.

\section{Birm-208. Lea Marston Pit, Coton, Warwicks \\ 9750 B.C. \\ (b) $11,170 \pm 160$ \\ 9220 B.c.}

Reed stems and fragments of coarser matted vegetation washed from bed (ca. $0.15 \mathrm{~m}$ thick) of gray silt and peat, lying at base of ca. $2.5 \mathrm{~m}$ of gravel on Keuper Marl in gravel under alluvial plain of $\mathrm{R}$. Tame 
at Lea Marston Pit, Coton, Warwickshire $\left(52^{\circ} 32^{\prime} 37^{\prime \prime} \mathrm{N}\right.$ Lat, $1^{\circ} 41^{\prime}$ 24" W Long, Grid Ref. SO210941). Coll. 1970 and subm. by F. W. Shotton. Sample (a) after alkali pretreatment, (b) humate extract. Comment (F.W.S.): dates beginning of sedimentation at site of alluviai plain. Assoc. insect fauna typical of early Zone II.

\section{Birm-215. Lea Marston, Warwickshire}

$9510 \pm 235$

7560 B.C.

Wood from ca. $2.74 \mathrm{~m}$ depth at base of peaty silt resting upon gravel referred to in Birm-208, above, at Lea Marston, Warwickshire (52 $32^{\prime}$ $40^{\prime \prime} \mathrm{N}$ Lat, $1^{\circ} 41^{\prime} 20^{\prime \prime} \mathrm{W}$ Long, Grid Ref. SO212942). Coll. 1970 and subm. by P. J. Osborne, Dept. of Geol., Univ. of Birmingham. Comment (P.J.O.): sample contains extensive beetle fauna of thermophilous assemblage suggesting summer temperatures similar to present but no indication of trees. This date and Birm-208 bracket period of gravel deposition.

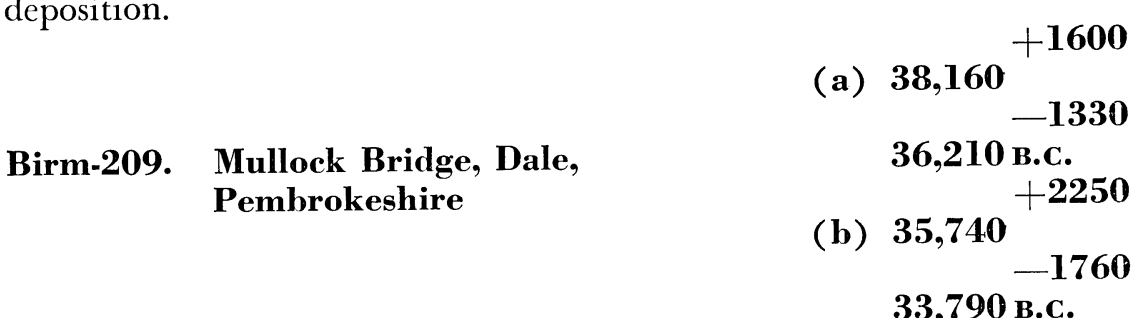

Inner (a) and outer (b) fractions of marine molluscs (Littorina) at $+18 \mathrm{~m}$ alt from Mullock Bridge Gravel pit, ca. $2.4 \mathrm{~km}$ from Dale on the Dale-Haverfordwest rd. (51 $43^{\circ} 00^{\prime \prime} \mathrm{N}$ Lat, $5^{\circ} 09^{\prime} 30^{\prime \prime} \mathrm{W}$ Long, Grid Ref. SN811075). Coll. 1970 and subm. by B. S. John, Dept. of Geog., Univ. of Durham. Comment: closely agrees with NPL-80, 37,960 +1700
-1400 (R., 1965, v. 7, p. 158), bulk sample of mollusc fragments from same site (John, 1965).

Birm-210. Asfordby, Leicestershire

$3610 \pm 90$

1660 B.c.

Wood washed from peat at base of alluvium (1.5 to $2.0 \mathrm{~m}$ thick) in flood plain of $\mathrm{R}$. Wreak at Asfordby, Leicestershire $\left(52^{\circ} 45^{\prime} \mathrm{N}\right.$ Lat, $0^{\circ} 57^{\prime} \mathrm{W}$ Long, Grid Ref. SK706185). Sample immediately overlies sand and gravel (2.0 to $2.5 \mathrm{~m}$ thick) dated at $37,420+1670$; (Birm-78, R., 1969, v. 11, p. 264). Coll. 1969 and subm. by R. J. Rice, Dept. of Geog., Univ. of Leicester. Comment: dates local beginning of alluviation along Wreak valley.

\section{Glanllynau series, Caernarvonshire, North Wales}

Plant material from base of kettle hole infilling which has a welldocumented pollen spectrum and coleopteran spectrum of Late Glacial age, at Glanllynau, Caernarvonshire, $\mathrm{N}$ Wales $\left(52^{\circ} 54^{\prime} 45^{\prime \prime} \mathrm{N}\right.$ Lat, $2^{\circ} 22^{\prime}$ 
45" W Long, Grid Ref. SH449373). Coll. 1970 and subm. by G. R. Coope, Dept. of Geol., Univ. of Birmingham.

\section{Birm-212.}

$14,468 \pm 300$

12,518 в.C.

Moss washed from silty clay $1.34 \mathrm{~m}$ below base of Zone I detritus mud. Comment (G.R.C.): dates start of Late Glacial infilling of kettle hole and an arctic/subarctic assemblage of coleoptera.

\section{Birm-232.}

$11,714 \pm 255$ 9764 B.C.

Plant debris from silty clay 22.5 to $25 \mathrm{~cm}$ below base of Zone I detritus mud. Comment (G.R.G.): obvious rootlets removed as far as was possible.

\section{Birm-233.}

$11,617 \div 270$ 9667 B.C.

Plant debris washed from silty clay 15 to $171 / 2 \mathrm{~cm}$ below base of Zone I detritus mud. Comment (G.R.C.): sample penetrated by vertical rootlets. These were removed by hand sorting as well as possible.

\section{Glen Ballyre series, Isle of Man}

Samples from Late Glacial sequence at Glen Ballyre near Kirkmichael, Isle of Man (54 $19^{\prime} 45^{\prime \prime} \mathrm{N}$ Lat, $4^{\circ} 36^{\prime} 00^{\prime \prime} \mathrm{W}$ Long, Grid Ref. SC315915). Coll. 1970 and subm. by G. R. Coope.

\section{Birm-213.}

$18,900 \pm 330$ 16,950 в. .

Moss fragments washed from clay at 2.90 to $2.97 \mathrm{~m}$ below cliff top. Comment (G.R.C.): date is minimum for Orisdale moraine. Sample assoc. with small assemblage of coleoptera and lies $25 \mathrm{~cm}$ below pollen Zone I deposits (Mitchell, 1965; Dickson, Dickson, and Mitchell, 1970).

\section{Birm-214.}

$12,645 \pm 280$

Plant fragments washed from detritus mud at 2.62 to $2.67 \mathrm{~m}$ below cliff top. Comment (G.R.C.): sample from early Zone I deposit, 12,210 \pm 120 (GRO-1616, R., 1967, v. 9, p. 81), contains temperate insect fauna (alpine valleys).

\section{Birm-217. Langham, near Rawcliffe, Yorkshire}

(a) $>42,200$ ably Pinus, with other wood fragments including Quercus? in sandy and clayey gravel below the 25-Foot Drift of the Vale of York in a borehole $823 \mathrm{~m} \mathrm{~W} 41^{\circ} \mathrm{S}$ of Rawcliffe R.R. Sta. and $21 \mathrm{~km} \mathrm{NNE}$ of Doncaster, Yorkshire (53 41'01" N Lat, $0^{\circ} 58^{\prime}$ 07" W Long, Grid Ref. SE68122133). Coll. 1970 and subm. by G. D. Gaunt, Inst. of Geol. Sci. Comment (G.D.G.): as overlying 25-Foot Drift is almost certainly late Devensian, infinite dates support conclusion from wood identifications that fragments are interglacial. Level of occurrence, -30 to $-35 \mathrm{ft}$ alt, is unusually low for an interglacial deposit in situ, however; wood possibly 
was reworked into a Devensian deposit. A palynologic study of deposit is in progress.

General Comment (R.E.G.W.): (a) and (b) represent 2 separate methane preparations using different sources of hydrogen.

\section{Birm-229. River Clarach, Aberystwyth, $\quad 10,100 \pm 250$ Cardiganshire \\ 8150 B.c.}

Basal peat lens at ca. $-2.0 \mathrm{~m}$ alt immediately behind storm beach at mouth of $\mathrm{R}$. Clarach, $2 \mathrm{~km} \mathrm{~N}$ of Aberystwyth, Cardiganshire $\left(52^{\circ}\right.$ $25^{\prime} 54^{\prime \prime} \mathrm{N}$ Lat, $4^{\circ} 04^{\prime} 35^{\prime \prime} \mathrm{W}$ Long, Grid Ref. SN587839). Coll. 1970 and subm. by J. A. Taylor, Dept. of Geog., Univ. Coll. of Wales, Aberystwyth. Comment: confirms pollen analysis which suggested Late Glacial age (Smith and Taylor, 1969).

\section{Birm-230. Rossall Beach, Fylde, Lancashire}

$12,320 \pm 155$

Fine to medium organic silt rich in macrofossils including Phragmites at -0.94 to $-0.99 \mathrm{~m}$ alt from peat bed in scoured depression in

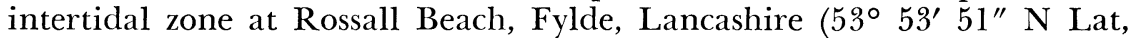
$3^{\circ} 02^{\prime}$ 54" W Long, Grid Ref. SD3111438). Coll. 1969 and subm. by M. J. Tooley, Dept. of Geog., Univ. of Durham. Comment: determination indicates late Zone I, whereas pollen suggests Zone II.

Birm-231. Wandle Valley, Mitcham, Surrey

$3353 \pm 134$

Driftwood from gravel in Wandle Valley at Mitcham, Surrey $\left(51^{\circ}\right.$ $24^{\prime} \mathrm{N}$ Lat, $0^{\circ} 09^{\prime} \mathrm{W}$ Long, Grid Ref. TQ279682). Coll. 1970 and subm. by D. S. Peake. Comment: gravel is clearly late Holocene, unconnected with deposits of Birm-101 (10,130 \pm 120 ; R., 1969, v. 11, p. 265) with Zone III date and arctic fauna.

Birm-234. Scandal Beck, Westmorland

$>\mathbf{3 2 , 5 0 0}$

Wood from upper of 2 organic horizons in sandy silt overlain by $1.5 \mathrm{~m}$ till ca. $5.8 \mathrm{~m}$ depth on W bank Scandal Beck, $64 \mathrm{~m}$ SSW Brunt Hill Farm, Ravenstonedale, Westmorland $\left(54^{\circ} 25^{\prime} \mathrm{N}\right.$ Lat, $2^{\circ} 24^{\prime} \mathrm{W}$ Long, Grid Ref. SE743024). Coll. 1970 and subm. by G. A. L. Johnson, Dept. of Geol., Univ. of Durham. Comment: earlier measurement on another sample (Birm-161, 36,300 +2160 ; R., 1970, v. 12, p. 386) suggested interstadial of last glaciation, but pollen is claimed to be interglacial. This 2nd sample appeared to be inactive, but was insufficient to give a high value for $4 \sigma$.

\section{Lea Valley, Edmonton, Middlesex 19,580 в.c.}

Plant material at +6.25 to $+6.86 \mathrm{~m}$ alt in sand and gravel overlying London Clay at Deephams Sewage Works, Edmonton, in Lea Valley, Middlesex (51 $37^{\prime} 30^{\prime \prime} \mathrm{N}$ Lat, $0^{\circ} 02^{\prime} 45^{\prime \prime} \mathrm{W}$ Long, Grid Ref. TQ357936). Coll. 1970 by P. Tallon; subm. by G. R. Coope. Comment 
(G.R.C.): dates arctic insect fauna. Deposit approx. equivalent to "Lea Valley Arctic Bed" (Q-25, 28,000 \pm 1500 ; R., 1960, v. 2, p. 65). Site close to classic locality of this bed at Ponders End (Godwin, 1956).

\section{Birm-239. Drumurcher, Co. Monaghan, Ireland}

$10,515 \pm 195$

8565 в.c.

Plant debris (terrestrial) washed from gray silty clay at ca. $2.4 \mathrm{~m}$ depth, overlain by brown muddy silt and underlain by gray sand at Drumurcher, Co. Monaghan, Ireland $\left(54^{\circ} 06^{\prime} 00^{\prime \prime} \mathrm{N}\right.$ Lat, $7^{\circ} 13^{\prime} 00^{\prime \prime}$ W Long, Grid Ref. H5218). Coll. 1970 and subm. by G. R. Coope. Comment (G.R.G.): sample from well below normal water table contains few or no intrusive roots. Establishes age of richest arctic insect fauna yet found in Ireland.

\section{British Antarctic Survey series}

\section{B. Miscellaneous Geologic Samples}

Samples of whale bone from emerged beaches in South Shetland Is. Coll. 1966 by D. E. Sugden; subm. by B. S. John.

\section{Birm-50.}

$1056 \pm 130$

Collagen from interior of Centrum solidly embedded in emerged beach at ca. $+3 \mathrm{~m}$ alt at $\mathrm{E}$ end of $\mathrm{S}$ beach of Byers Peninsula, Livingston I., Antarctica $\left(62^{\circ} 40^{\prime} \mathrm{S}\right.$ Lat, $60^{\circ} 56^{\prime} \mathrm{W}$ Long).

\section{Birm-224.}

$1390 \pm 140$

Collagen from rib lying on emerged beach at ca. $+7.6 \mathrm{~m}$ alt at $\mathrm{S}$ coast of Barton Peninsula, King George I., Antarctica $\left(62^{\circ} 14^{\prime} \mathrm{S}\right.$ Lat, $58^{\circ} 47^{\prime}$ W Long).

General Comment: possibility of hard-water effect (Broecker, 1963) making these samples indistinguishable from recent animals.

\section{Oberbayern series, Germany}

Wood (now strongly compressed to lignite) in sediments which antedate Main Würm glaciation and which are claimed by E. Ebers to belong to mid-Würm interstadial rather than to Riss/Würm interglacial (Ebers, 1965; Reich, 1952; 1953). Coll. between 1967-1969 and subm. by E. Ebers.

\section{Birm-178. Zeifen, Oberbayern, Germany $\quad 33,850$ B.c.}

Lignite lying above Zeifen Riss/Würm interglacial and below Laufen Gravel and drumlinized till of Main Würm at Post Petting, Oberbayern, Germany, in foreland of Bavarian Alps $\left(47^{\circ} 56^{\prime} \mathrm{N}\right.$ Lat, $12^{\circ}$ $49^{\prime}$ E Long).
Birm-203. Lech, Oberbayern, Germany
43,650 в.C.
$+2000$
Wood in lacustrine beds of former Lech Glacier in foreland of 
Bavarian Alps at Schlogel-Muhle bei Steingaden, Lech, Oberbayern, Germany ( $47^{\circ} 42^{\prime} \mathrm{N}$ Lat, $10^{\circ} 52^{\prime} \mathrm{E}$ Long).

\section{Birm-237. Grossweil, Oberbayern, Germany 40,415 B.c.} $-1320$

Lignite overlain by moraine and underlain by gravel and blue clay in former coal mine at Grossweil, Oberbayern, Germany $\left(47^{\circ} 40^{\prime} \mathrm{N}\right.$ Lat, $11^{\circ} 18^{\prime}$ E Long).

General Comment (F.W.S.): spread of dates supports interstadial age, around time which, in Britain, was one of mild climate (Upton Warren phase). All samples pretreated with $\mathrm{NaOH}$ but appeared uncontaminated.

\section{Birm-180. Tenerife, Canary Islands}

(a) $>25,200$

Carbonized wood from impermeable ignimbrite overlying extensive air-fall pumice deposit (Granadilla pumice) assoc. with latest massive explosive eruption of Tenerife volcano. Sample from quarry $2 \mathrm{~km} \mathrm{NE}$ of Los Cristianos on S slope of shield volcano at Tenerife, Canary Is. (28 $03^{\circ} \mathrm{N}$ Lat, $16^{\circ} 41^{\prime} \mathrm{W}$ Long). Coll. 1968 and subm. by G. P. L. Walker, Geol. Dept., Imperial College, London. Comment (R.E.G.W.): sample partially broke down during acid pretreatment giving a heavy oily organic liquid, which was filtered off and residue, after evaporation, dated as filtrate (a). Remaining solid was insufficient for alkali pretreatment and dated as sample (b).

\section{Azores Volcanic series}

Birm-181. San Miguel, Azores

$663 \pm 105$

Carbonized wood enclosed in pumice ash of crater wall on S flank of Caldeira Secca, $300 \mathrm{~m} \mathrm{~S}$ of center of core of Sete Cidades at W end of I. of San Miguel, Azores (37 $51^{\prime} \mathrm{N}$ Lat, $24^{\circ} 48^{\prime} \mathrm{W}$ Long). Coll. 1969 and subm. by G. P. L. Walker. Comment (G.P.L.W.): represents one of latest explosive eruptions of Sete Cidades volcano.

\section{Birm-225. Furnas, San Miguel, Azores}

$2900 \pm 120$

Fossil wood from permeable ash deposit on rim of Furnas Caldera $0.6 \mathrm{~km} \mathrm{~W}$ of Lagoa Furnas and $1.2 \mathrm{~km}$ ENE of peak Cedros, San

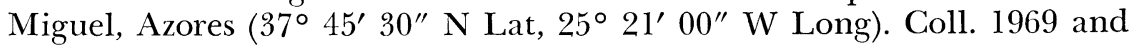
subm. by G. P. L. Walker. Comment: sample younger than Fogo A pumice deposit dated as Birm-35, $4672 \pm 100$ (R., 1968, v. 10, p. 204) and Birm-90, $4435 \pm 99$ (R., 1969, v. 11, p. 266).

\section{Baie d'Ecalgrain series, Manche, France}

Plant material washed from lower of 2 thin beds of peaty silt at base of cliff, separated by thin head, lying on gravel and rock platform of Normannian beach, and overlain by thick (ca. 30 to $40 \mathrm{~m}$ ) coarse 
head at Baie d'Ecalgrain, Manche, France $\left(49^{\circ} 41^{\prime} 30^{\prime \prime} \mathrm{N}\right.$ Lat, $1^{\circ} 56^{\prime}$ $30^{\prime \prime}$ W Long) (Ters and Pinot, 1969).

Birm-183.

$>37,000$

Small sample coll. 1969 and subm. by F. W. Shotton.

(a) $\quad 40,750$

Birm-211.

(b) $>$ 44,500

Part of much larger sample coll. 1970 and subm. by C. Larsonneur, Dept. of Geol., Univ. of Caen, Calvados, France. Visibly contaminated with modern rootlets. (a) washed sample, all recognizable rootlets removed and alkali treated; (b) was result of gasifying a small quantity of washed-out twigs (uncontaminated) and adding this to gas of (a) in proportions $9 / 19$.

General Comment (F.W.S.): Birm-211(a) clearly still contaminated and date must be early to mid-Weichselian or possibly Eemian. Pollen suggests open country with predominance of Pinus and Betula (Elhai, 1962) and assoc. beetle fauna indicates cool climate. Earlier date of 12,600 \pm 400 must be erroneous (Gif-368, R., 1969, v. 11, p. 328).

\section{Birm-204. Kinabalu, North Borneo}

$6800 \pm 175$

Fine detritus mud from 40 to $45 \mathrm{~cm}$ depth below mud surface in sacrificial pool at foot of Low's Peak, Mt. Kinabalu, Sabah, N. Borneo $\left(6^{\circ} 05^{\prime} \mathrm{N}\right.$ Lat, $116^{\circ} 35^{\prime} \mathrm{E}$ Long). Coll. 1969 and subm. by J. R. Flenley, Dept. Geog., Univ. of Hull. Comment: date is minimum for start of organic accumulation and for deglaciation at this alt, ca. $4020 \mathrm{~m}$ (Koopmans and Stauffer, 1968; Newton-Smith and Wilford, 1969; Stauffer, 1968).

\section{Birm-205. Kuim, Tasek Bera, Malay Peninsula 2546 B.C.}

Course detritus mud from 8.25 to $8.45 \mathrm{~m}$ depth below water level at Kuim, Tasek Bera, Pahang, Malay Peninsula $\left(3^{\circ} 10^{\prime} \mathrm{N}\right.$ Lat, $102^{\circ} 35^{\prime}$ E Long). Coll. 1969 and subm. by J. R. Flenley. Comment: date is minimum for start of organic accumulation and also possibly for diversion of R. Pahang.

\section{Tofua Island series, Tonga}

Part of carbonized tree trunk from base of pyroclast succession in fine-grained gray andesitic ash $200 \mathrm{~m} \mathrm{~S}$ of Hota'ane on W coast of Tofua I., Tonga $\left(19^{\circ} 48^{\prime} \mathrm{S}\right.$ Lat, $175^{\circ}$ 04' W Long). Coll. 1969 and subm. by P. E. Barker, Dept. of Earth Sci., Univ. of Leeds.

Birm-216.

$970 \pm 50$

A.D. 980 
Birm-241.

$1032 \pm 105$

A.D. 918

Comment: estimated age ca. 25,000 B.P. Two separate determinations done on different material of same sample agree, but material clearly intrusive.

Birm-226. Lota Coal Mine, Victoria, Chile

Coalified wood from Pliocene unconformity at $350 \mathrm{~m}$ level in Lota Coal Mine ca. $3.2 \mathrm{~km} \mathrm{~W}$ of Lota under Bay of Arauco, Victoria, Chile ( $37^{\circ} 08^{\prime} \mathrm{S}$ Lat, $73^{\circ} 00^{\prime} \mathrm{W}$ Long). Coll. 1970 by unnamed Chilean miners; subm. by R. H. Allonby, Natl. Coal Bd. Comment: miners believed sample part of old pit prop from previous workings but position under sea made this impossible. Determination precludes pit prop theory.

\section{B.C.}

Carbonized branch imbedded in Wanganui pumice gravel $\mathrm{S}$ side of rd. sec. State Hwy. 47 at Tongariro, North I., New Zealand (39 $03^{\prime}$ $40^{\prime \prime} \mathrm{S}$ Lat, $175^{\circ} 35^{\prime} 00^{\prime \prime}$ E Long). Coll. 1969 and subm. by C. A. Fleming. Comment: repeat of Birm-145, $2600 \pm 100$; R., 1970, v. 12, p. 394), made on another piece of wood from same branch, inexplicably discrepant. Pretreatment was the same for both; extraction of rootlets followed by full acid and alkali treatment. Birm-145 very different from Inst. Nuclear Sci., New Zealand date (unpub.) on sample from same branch (1925 \pm 66 before arbitrary subtraction of $100 \mathrm{yr}$ for Suess effect). Birm-235 is closer to NZ result but still needs explanation of a significant difference; $\mathrm{NZ}$ correction for $\delta \mathrm{C}^{13}$ of -30.2 would account for 83 yr difference, placing the 2 dates into comparative ranges. Birm- 145 must be erroneous.

\section{ARCHAEOLOGIC SAMPLES}

\section{A. British Isles}

\section{St. Bertelin's Chapel series, Staffordshire}

Samples of wood and charcoal from church yard at St. Bertelin's Chapel, Stafford (52 $49^{\prime} \mathrm{N}$ Lat, $2^{\circ} 07^{\prime} \mathrm{W}$ Long, Grid Ref. SJ919235). Coll. 1954 by A. Oswald; subm. by P. H. Robinson.

Birm-137.

$770 \pm 78$

Oak believed part of cruciform coffin of St. Bertelin.

\section{Birm-136.}

$$
\begin{aligned}
& \text { (a) } 1105 \pm 90 \\
& \text { A.D. } 845 \\
& \text { (b) } 1120 \pm 120 \\
& \text { A.D. } 830
\end{aligned}
$$

Charcoal assoc. with wood remains believed cruciform coffin of St. Bertelin. Determinations done on separate portions of same material but methane prepared from different hydrogen sources. 
General Comment: close correspondence of Birm-136(a) and (b) suggests validity of date. It could have been a wooden object from a Saxon church, for such material was burnt when no longer required. Unless contaminated, Birm-137, which is probably wood of a coffin, must be later and not connected with St. Bertelin.

\section{Birm-185. Croft Ambrey, Herefordshire}

(a) $2410 \pm 135$

460 B.C.
(b) $2377 \pm 136$ 427 B.c.

Charcoal from large timbers on rd. at SW gateway of Croft Ambrey Hill Fort, Aymestry, Herefordshire (52 $2^{\circ} 18^{\prime} \mathrm{N}$ Lat, $2^{\circ} 49^{\prime} \mathrm{W}$ Long, Grid Ref. SO445668). Coll. 1964 and subm. by S. C. Stanford, Dept. of Extramural Studies, Univ. of Birmingham. Sample (a) after alkali pretreatment, (b) humate extract. Comment: dates destruction of guardrooms of Iron age fort and accords closely with comparable fortification at Midsummer Hill (Birm-142, $2370 \pm 190$; Birm-143, $2000 \pm 100$; R., 1970, v. 12, p. 396). Birm-144 from Croft Ambrey still remains anomalously old $(3000 \pm 200)$.

\section{Cannington series, Somerset}

Collagen extracted from bone samples from different graves in Christian burial ground near mouth of R. Parret, Cannington, Somerset $\left(51^{\circ} 09^{\prime} \mathrm{N}\right.$ Lat, 3 04' W Long, Grid Ref. ST252404). Coll. 1963 and subm. by P. A. Rahtz, School of Hist., Univ. of Birmingham.

\section{Birm-186.}

(a) $1320 \pm 160$

A.D. 630

(a) $1370 \pm 230$ A.D. 580

Two determinations done on different rib bones from same skeleton (Grave 424) agree with determination from same site (Birm-70, $1220 \pm$ 110; R., 1969, v. 11, p. 268) but different grave (Grave 409).

Birm-193.

Sample from Grave 402.

Birm-194.

Sample from Grave 197.
$1610 \pm 105$ A.D. 340

$1685 \pm 100$ A.D. 305

General Comment: Birm-193 and Birm-194 so closely agree and are, apparently, so much younger than Birm-70 and Birm-186, they suggest a cemetery overlapping conversion to Christianity.

\section{Mam Tor series, Derbyshire}

Samples from Mam Tor Hill Fort, Derbyshire $\left(53^{\circ} 21^{\prime} 00^{\prime \prime} \mathrm{N}\right.$ Lat, $2^{\circ} 51^{\prime} 30^{\prime \prime} \mathrm{W}$ Long, Grid Ref. SK 128837). Coll. 1968 and subm. by D. G. Coombs, Dept. of Hist., Univ. of Manchester. 
Birm-202.

Charcoal from layer into which gulleys and post holes were cut for hut, in NE corner of site behind rampart.

Birm-192.

$3080 \pm 115$

Charcoal from same layer as Birm-202 but $\mathrm{E}$ of hut in NE corner of site (Coombs, 1967).

General Comment: dates agree well but are older than expected. Estimated age: 2500 B.P.

\section{Birm-198. King's School, Worcester}

$1414 \pm 107$

Collagen from human rib bones of uncoffined burial (Grave 1) below foundations of wall built in 17th century A.D. at Undercroft, College Hall, King's School, Worcester $\left(52^{\circ} 11^{\prime} 20^{\prime \prime}\right.$ N Lat, $2^{\circ} 13^{\prime} 15^{\prime \prime}$ W Long, Grid Ref. SO850545). Coll. 1969 and subm. by P. A. Barker, Dept. of Extramural Studies, Univ. of Birmingham. Comment: estimated age very vague, between 400 and 1200 A.D.

\section{Sharpstones Hill series, Shrewsbury}

Samples from fill of pit containing cremation debris of supposed Late Bronze age at Sharpstones Hill, Shrewsbury $\left(52^{\circ} 41^{\prime} \mathrm{N}\right.$ Lat, $2^{\circ} 44^{\prime}$ W Long, Grid Ref. SJ508106). Coll. 1965 and subm. by W. E. Jenks, Shropshire Archaeol. Soc.

\section{Birm-206.}

Charcoal from Site B, F49.

\section{B.C.}

\section{Birm-207.}

$2970 \pm 118$

Charcoal from Site B, F57.

General Comment: confirms cremation cemetery is of Late Bronze or Middle Bronze age and dates assoc. pottery which is atypical.

\section{Ryton-on-Dunsmore series, Warwickshire}

Samples from Bronze/Iron age settlement and cemetery near Ryton Wood at Ryton-on-Dunsmore, Warwickshire $\left(50^{\circ} 20^{\prime} 56^{\prime \prime} \mathrm{N}\right.$ Lat, $1^{\circ} 27^{\prime}$ 22" W Long, Grid Ref. SP371723) on parish boundary with Bubbenhall. Coll. 1970 and subm. by J. Bateman.

\section{Birm-227.}

$$
2785 \pm 120
$$

Charcoal from $0.6 \mathrm{~m}$ down in ditch $0.8 \mathrm{~m}$ deep. Comment: indicates Late Bronze age for sample (see also Birm-26, $2701 \pm 41$; R., 1968, v. 10, p. 204).

\section{Birm-228.}

$$
\begin{aligned}
& 2870 \pm 106 \\
& 920 \text { B.C. }
\end{aligned}
$$

Charcoal from a cremation pit beneath 40 to $50 \mathrm{~cm}$ of plough soil. Comment: indicates Late Bronze age for sample. 


\section{B. Miscellaneous Archaeologic Samples}

\section{Birm-182. Ayios Epikitos Vrysi, Cyprus}

Hearth material underlying yellow clay at $1.8 \mathrm{~m}$ depth, $10.5 \mathrm{~km} \mathrm{E}$ of Kyrenia on coast at Ayios Epikitos Vrysi, Cyprus $\left(35^{\circ} 40^{\prime} \mathrm{N}\right.$ Lat, $33^{\circ}$ 26' E Long). Coll. 1969 and subm. by P. S. Gelling, Dept. of Ancient Hist. and Archaeol., Univ. of Birmingham. Comment: agrees well with estimated age of occupation of site of ca. 4000 B.c.

Birm-199. Alicante, Spain

Charcoal from Catí Foradá, Petrel, Alicante, Spain (38 $30^{\prime} 34^{\prime \prime}$ N Lat, 20 59' 40" E Long). Coll. 1969 and subm. by M. J. Walker, Dept. of Anatomy, Univ. Medical School, Edinburgh. Comment: estimated age: $3500-4500$ B.P.

\section{Birm-200. Murcia, Spain}

$$
\delta \mathrm{C}^{14 \% \circ}=-\mathbf{1 6 . 7} \pm \mathbf{1 3 . 3}
$$

Charcoal trom dry limestone rock shelter at Barranco de los Grajos, Cieza, Murcia, Spain (38 $16^{\prime} 00^{\prime \prime} \mathrm{N}$ Lat, $2^{\circ} 18^{\prime} 53^{\prime \prime} \mathrm{E}$ Long). Coll. 1969 and subm. by M. J. Walker. Comment: it was hoped to ascertain date of flint and ceramic industry assoc. with nearby rock paintings of Early Neolithic attribution (estimated age: 5000-8000 B.P.). Sample clearly intrusive and could be explained by evidence of recent disturbance of earth in which sample lay.

\section{REFERENCES}

Bell, F. G., 1968, Weichselian glacial floras in Britain: Ph.D. dissert., Univ. of Cambridge.

1969, The occurrence of southern steppe and halophyte elements in Weich-

Broecker, W. S., 1963, Radiocarbon ages of Antarctic materials: Polar Record, v. 11, no. 73 , p. 473

Coombs, D. G., 1967, Interim report on 1967 excavation: Derbyshire Archaeol. Jour., v. 87, p. $158-159$

Dickson, C. A., Dickson, J. H., and Mitchell, G. F., 1970, The Late Glacial flora of the Isle of Man: Royal Soc. [London] Philos. Trans., v. 259, p. 31-79.

Ebers, E., 1965, Evidence of an older Würm glacial maximum and a middle Würm Interstadial in the Alps, in: Studies in Earth Sci., no. 7, VII INQUA Congress Proc., v. 14, Boulder, Colorado.

Elhai, H., 1962, Analyse pollinique d'un dépôt organique intercalé dans le head d'Ecalgrain: Soc. Linn. de Normandie Bull, v, 10, no. III, p. 93-95.

Godwin, H., 1956, The history of the British flora: Cambridge, Cambridge Univ. Press.

Jamieson, T. F., 1906, The Glacial period in Aberdeenshire and the southern border of the Moray Firth: Quart. Geol. Soc. London Jour., v. 62, p. 13-39.

Jardine, W. G., 1967, The Post-glacial marine transgression at Girvan, Ayrshire: Inst. Br. Geog. Trans., no. 42, p. 181-182.

John, B. S., 1965, A possible Main Würm glaciation in West Pembrokshire: Nature, v. 207, p. $622-623$

Koopmans, B. N. and Stauffer, P. H., 1968, Glacial phenomena on Mount Kinabalu, Sabah: Borneo Region, Malaysia Geol. Survey Bull., v. 8, p. 25-35.

Mitchell, G. F., 1965, 'The Late Quaternary of the Ballaugh and Kirkmichael districts, Isle of Man: Geol. Soc. London Quart. Jour., v. 21, p. 359-381.

Morgan, A., 1970, Weichselian insect faunas of the English Midlands: Ph.D. dissert., Univ. of Birmingham.

Morgan, A. V., 1970, The glacial geology of the area North and West of Wolverhampton: Ph.D. dissert., Univ. of Birmingham. 
Newton-Smith, J. and Wilford, G. E., 1969, Radiocarbon age determination on wood from Kambawangoh, Sabah: Borneo Region, Malaysia Geol. Survey Bull., v. 9, p. 36-7.

Penny, L. F., 1964, A review of the last glaciation in Great Britain: Yorkshire Geol. Soc. Proc., v. 34, pt. 4, no. 20, p. 387-411.

Read, H. H., 1923, The geology of the country round Banff, Huntly and Turriff: Geol. Survey Mem., Explanation of Sheets 86 and 96.

Reich, H., 1952, Zur vegetationsentwicklung des interglaziale von Grosswell: Eiszeitalter und Gegenwart, v. 2, p. 108-119.

1953, Die vegetationsentwicklung der interglaziale von Grossweil-Ohlstadt und Pfefferbichl im Bayerischen Alpenvorland: Flora, v. 140, p. 386-443.

Shotton, F. W., 1967, Age of the Irish Sea Glaciation of the Midlands: Nature, v. 215 no. 5108 , p. 1366.

Sissons, J. B., 1967, Glacial stages and radiocarbon dates in Scotland: Scot. Jour. Geol., v. 3 , pt. 3 , p. $375-381$.

Smith, R. T. and 'Taylor, J. A., 1969, Post glacial development of vegetation and soils in North Cardiganshire: Inst. Br. Geog. Trans., no. 48, p. 75-96.

Stauffer, P. H., 1968, Glaciation of Mount Kinabalu: Geol. Soc. Malaysia Bull., no. 1, p. 63.

Ters, M. and Pinot, J. P., 1969, Livret-Guide de l'excursion A.10, Littoral Atlantique: VIII INQUA Congress Proc., Paris. 